\title{
$X V$. On the order of the upper strata of the south- east part of England. Deduced from a series of observations made for Sir Henry Englefield, in the years $1811,-12$, and-13
}

\section{Thomas Webster Esq. M.G.S.}

To cite this article: Thomas Webster Esq. M.G.S. (1817) XV. On the order of the upper strata of the south-east part of England. Deduced from a series of observations made for Sir Henry Englefield, in the years 1811,-12, and-13, Philosophical Magazine Series 1, 49:225, 65-68, DOI: $10.1080 / 14786441708637838$

To link to this article: http://dx.doi.org/10.1080/14786441708637838

$$
\text { 曲 Published online: } 27 \text { Jul } 2009 .
$$

Submit your article to this journal ए

\section{山ll Article views: 2}

Q View related articles ¿ 
apparatus. $A$ is a common air-tight stove ${ }^{*} ; a$, a flexible hose bringing the fire-damp from its lodgement to the source of heat; 66 two metallic canals, one on either side, that opposite to the hose supplying atmuspheric air as a pabulum for the combustion. This air is not suffered to mingle with the fire-damp. below the bars of the grate, consequently explosion will not take place; and it will not burn at the orifice of the metallic canal, there being no oxygenous medium to support it; $c c$ are two dampers which may be shut when the door of the stove is opened to admit a fresh supply of fuel; $d$ is an air-tight drawer to receive the ashes.-It may be unnecessary to be more explanatory.

London, Jan. 21, 1817.

I am, with bigh respect, sir, Your obliged and very humble servant,

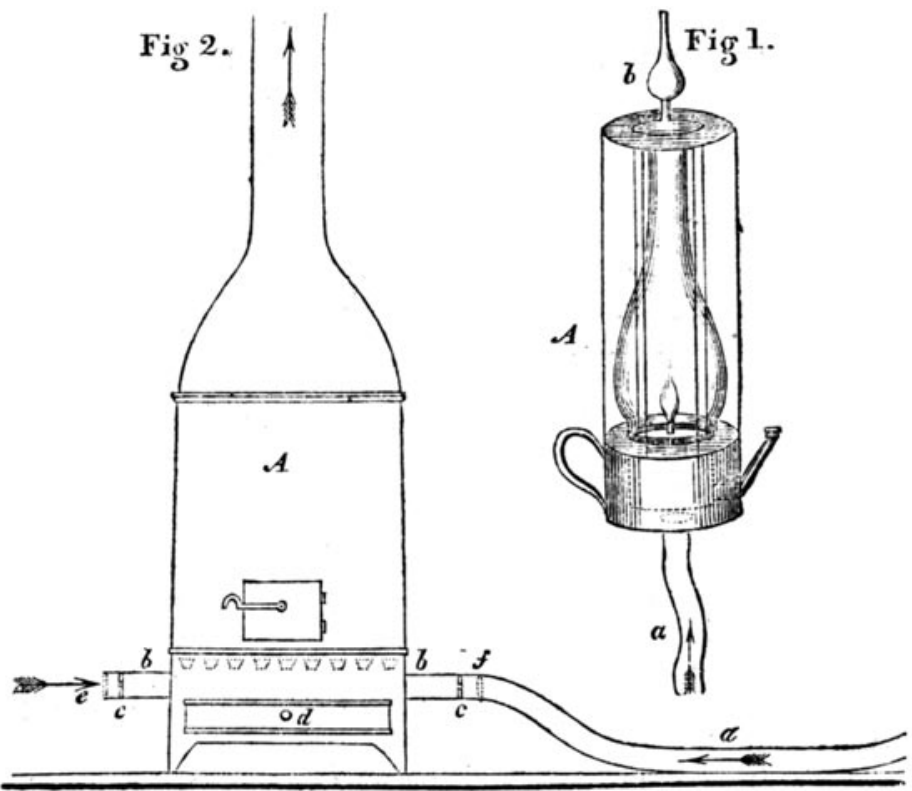

XV. On the Order of the Upper Strata of the South-east. Part of England. Deduced from a Series of Olservations made for Sir Henry Englefield, in the Years 1811,-12, and-13, by Thomas Webster, Esq. M. G. S†.

Alluvium. The ruins or detritus of regular strata, formed either by the present existing causes, or by some extraordinary

* Placed under the upcast shaft.

f From Sir Henry C. Englefield's superb work, a " Deseription of the principal picturesque Beauties, Antiyuities, and Geological Phænomena of the Isle of Wight." 1816.

Vol, 49. No, 225, Jan, 1817.

E

and 
and unknown agents. It is eomposed chiefly of water-worn fragments of flints, mixed with sard and clay in various proportions.

Upper Freshuater Formation.-This (ir the Isle of Wight) eonsists of a calcareous rock, in which numerous fossil freshwater shells are imbedded. It agrees in character and situation with the corresponding formation in the basin of Paris, and other parts of the continent of Europe. Traces of a freshwater formation are to be observed also in the London basin, between the alluvium and London clay, consisting of marl with freshwater shells, and containing also numerous bones of land animals, as the elephant, hippopotamus, buffalo, elk, ox, \&c. These have been found chielly at Sheppey, Brentford, Essex, Suffolk, and Norfolk. In other places, as at Sheppey, Emsworth in Sussex, \&c. vast quantities of the fruits of tropical countries have been found in a corresponding situation.

Upper Marine Formation.-This bed consists of blueish or greenish marl and clay containing a great number of fossil marine shells, which in general are different from those found in the London ctay. It is known in this country with certainty only in the Isle of Wight.

Lower Freshwater Formation.-This formation is ascertained in the Isle of Wight. It is placed under the last, and consists of clay, marl, and sand, with vegetable matter resembling an imperfect coal or peat, and contains numerous fragments of freshwater shells. At the bottom is found a mixture of marine with fresh-water shells. As the alternation of marine with fresh-water strata has not been observed in any other part of this country except the Isle of Wight, the traces of a fresh-water formation in the London basin cannot perhaps be referred to this.

Sand without Shells. - In the Isle of Wight this sand is extremely pure; it is dug at Alum Bay, and is used for making the best glass. The Basshot sand perhaps belongs to this, and possibly the Grayweathers; but the positions of these have not yet been accurately determined.

London Clay.-This is the blue clay of London, Highgate, Brentford, Sheppey, Portsmouth, Stubhington, Hordwell, Southend, Harwich, \&c. It is distinguished by its septaria, and its beautiful and numerous organic remains. In Alum Bay it is the most northerly of the vertical strata. Bognor Rocks are subordinate to this bed. It agrees in its fossils and geognostic situation with the lower beds of the calcaire grossiere of the Paris basin.

Plastic Clay.and Sand.-The clay in this formation is often extremely pure, and fit for the potter. It is much employed in the potteries in Staffordshire. It is in Alum Bay, the trough 
trough of Poole, and at the bottom of the blue clay in many parts of the London basin. An imperfect coal, or lignite, also frequently occurs in it. This formation corresponds to the French plastic clay, which lies over their chalk.

Chalk with Flints. - This formation in England extends from Flamborough-head in Yorkshire to a little beyond Lyme Regis in Deronshire [Dorsetshire]; and, where it is not covered by the beds above, forms chalk-hills or downs. It is distinguished by the regular layers of flint nodules.

Chalk without Flints.-The inferior bed of chalk in the southeast part of England is always without fints. When the chalk with flints is wanting, it forms the surface. The relations of both may be seen at the Culver and Compton Bay in the Isle of Wight, Handfast-point, Beachyhead, Guildford, Dorking, \&c. It differs from the former only in the absence of fints, in the beds being thicker, and the chalk being sometimes a little harder.

Chalk Marl.-This bed consists of chalk and an intimate mixture of clay.' It is always found below the two last strata. It may be readily distinguished from chalk, by its falling to pieces on being wetted and dried again. Some varieties of it, when burnt, form an excellent cement for building. It is also a valuable manure.

Green Sand-stone.- The formation to which I have given this name, consists of siliceous sand united by calcareous matter, and contains also mica and green earth. From the variety in the proportion of the latter ingredient, it is by some divided into the green sand and gray sand; a distinction which cannot always be made, since these alternate, and pass into each other. It is found in the wealds of Kent and Sussex, at the foot of the chalk downs, and is dug at Rygate and Mearsham for firestone. It is seen also at Folkstone, Beachyhead, the Culver and Compton Bay in the Isle of White, Pewsey in Wiltshire, \&c. Alternating with it are often beds of limestone, as at Maidstone in Kent, where they are called Kentish rag; also in the Undercliff, Isle of Wight, beds of chert occur in it. It abounds in organic remains.

Blue Marl.-This bed may be seen under the former very distinctly in the Isle of Wight; as at Sandown Bay, many parts of the Undercliff, Niton, and Compton. It contains very few fossils.

Ferruginous Sand.-This denomination is given also to an alternating series of siliceous sandstone, clay, and limestone: the sandstone contains always more or less oxide of iron, sometimes in such quantity, as in the wealds of Kent and Sussex, that it was formerly [and still occasionally at Ashburaham] employed as E 2 
an iron ore. The clay tracts of the Wealds belong to it. This formation may be also seen at Sandown Bay, Blackgang, and Compton chines, Swanwich-bay, Hastings, Tonbridge Wells, \&c. Fossil shells are rarely found in it, but carbonized wood is met with in abundance.

Purbeck Shell Limestone.-This formation consists of numerous beds of shells and fragments of shells cemented together by calcareous spar, and alternating with shells and marl. The Purbeck, and perhaps the Petworth marbles, form part of this series : and it is further remarkable for containing numerous freshwater shells, and bones of the turtle : hence it is not improbable that part of it may have been formed in fresh water.

Clay wilh Gypsum.-At Swanwich in Dorsetshire this is dug. under the shell limestone. The gypsum does not occur in great quantity, but is employed for plaster.

Portland Oolite. This includes the stone of Tillywhino and Windspit quarries, called the Purbeck Portland, and that from Portland island. It is entirely calcareous, and is formed of small grains or concretions adhering together. It is the only stone used for the fronts of public buildings in London. Some of its beds contain many marine fossils, also fossil wood and chert.

Bituminous Shale containing the Kimmeridge Coal.-This maybe seen at Kimmeridge, Encombe, and the Isle of Portland. It is the lowest stratum visible in that part of the country to which the above olservations have extended.

\section{Notices respecting New Books.}

$M^{\mathrm{r}}$.Murray's Elements of Chemical Science, second edition, with additions, is in the press, and will be forthwith published by Messrs. Underwood of Fleet-street.

This edition will contain a succinct and lucid view of those discoveries which have of late distinguished the rapid and brilliant march of chemical science.

The article on safety-lamps for mines, and account of experiments made by the new blow-pipe with a condensed mixture of oxygen and hydrogen, will possess considerable interest.

Dr. Spurzheim is engaged in publishing a full reply to the various reviews and other writers who have opposed his peculiar. doctrine of the brain.- His large work on Insanity is nearly ready for the press.

Mr. Copland Hutchison, late Surgeon to the Royal Naval Hospital at Deal, \&c. has in the press "Some further Observations on the Subject of the proper Period for amputating in Gun-shot Wounds; accompanied by the official Reports of the Surgeons employed in His Majesty's Ships and Vessels at the late Battle before Algiers." 